\title{
TINJAUAN TENTANG KEMAMPUAN MOTORIK HALUS DENGAN KEGIATAN KOLASE SEBAGAI PERSIAPAN MENULIS ANAK TUNA GRAHITA RINGAN
}

\author{
Satna Moniru1, Rosita Wondal'2, Rita Samad ${ }^{3}$, Nurhamsa Mahmud4, \\ Universitas Khairun \\ Fakultas Keguruan dan Ilmu Pendidikan \\ Jl. Bandara Sultan Baabullah Kota Ternate Utara, Kotak Pos 53 Ternate 977328 \\ Telepon: (0921) 3110905-Faksimili 0921-3110901 \\ Email : Tsatnamoniru@gmail.com¹, Rositawondal80@gmail.com²., ritasamad5@gmail.com³, \\ nurhamsaaca@gmail.com ${ }^{4}$
}

\begin{abstract}
Abstrak: Motorik halus merupakan kemampuan mengkoordinasikan gerakan-gerakan fisik yang melibatkan bagian-bagian tubuh tertentu saja dan dilakukan oleh otot-otot kecil, seperti jari jemari tangan dan gerakan pergelangan tangan dan koordinasi mata. Adapun salah satu kegiatan yang dapat diterapkan dalam mengembangkan kemampuan motorik halus anak yaitu dengan menggunakan kegiatan kolase guna mengembangkan kemampuan motorik halus. Kegiatan kolase dalam kajian ini adalah menghias pada kertas polos dengan teknik menempel. Adapun cara yang dilakukan dalam kegiatan ini yaitu kertas polos bentuk segiempat buat bentuk pola dengan cara menggaris pada beberapa bagian kertas menggunakan pensil atau spidol warna dan membentuk pola sesuai dengan keinginan kemudian pemberian lem pada bagian yang akan di tempel dengan bahan alam sehinga membentuk sebuah karya yang di inginkan oleh anak tuna grahita ringan. Metode yang digunakan dalam penelitian ini dengan pendekatan studi literatur (library research). Dari hasil penelitian dapat disimpulkan bahwa dengan menerapkan kegiatan kolase dapat membantu mengembangkan kemampuan motorik halus anak tuna grahita ringan.
\end{abstract}

Kata kunci: Kegiatan Kolase, Motorik Halus, Anak Tuna grahita Ringan.

Abstract: The soft skills as the capability to organize the physicals movements that involved some parts of the body and did by small sinews, such as fingers, arm, and eye coordination. The Kolasa is one activity to enhance the soft skills of the child. Kolasa's activity, in this study, is to examine be decorated at the white paper by stamp. The procedure of this activity is a quadrangle of white paper make a ball by doing some lines in some parts by pencil or colors board makers into a ball based on what the children want to do and then put the glue to the environment materials in order to make a great create based on the wish of the mentally challenged child. The methodology of this study is library research. Based on the results, the author concludes that by doing Kolasa activity can help to enhance the soft skills achievement of the child.

Keywords: Kolasa Activity, Soft skills, the mentally challenged child.

\section{A. Pendahuluan.}

Pendidikan anak usia dini merupakan salah satu bentuk penyelenggaraan yang menitiberatkan pada pelatihan dasar kearah pertumbuhan dan enam aspek perkembangan yaitu: perkembangan moral dan agama, perkembangan fisik, kordinasi motorik kasar dan halus, kecerdasan/kognitif daya pikir dan daya cipta, sosialemosional sikap dan emosi, bahasa dan komunikasi, solusi dangan keunikan dan tahap-tahap perkembngan sesuai dengan kelompok usia yang dilalui oleh anak usia dini. Anak usia dini adalah individu yang mengalami proses pertumbuhan dan perkembangan yang sangat pesat, anak usia dini memiliki rentang usia yang sangat berharga disbanding usia selanjutnya karena perkembangan kecerdasaannya sangat luwar biasa. Usia tersebut merupakan fase kehidupan yang unik, dan berada pada masa proses perubahan berupa pertumbuhan, perkembangan, pematangan, dan penyempurnaan, baik dalam aspek jasmani maupun rohaninya yang berlangsung seumurhidup, serta bertahap dan berkesinambungan. Setiap anak memiliki 
karakteristik perkembangan yang berbeda-beda, yaitu dalam proses utama perkembangan anak merupakan hal yang paling penting dalam kehidupan anak. Anak merupakan generasi penerus yang harus diberikan stimulasi yang sangat baik dalam tahap pertumbuhan dan perkembangannya, dimana anak harus diberikan pendidikan sejak dini untuk mengoptimalkan semua aspek perkembangan yang ada pada diri anak. Karena anak yang distimulasikan dengan baik maka bukan hanya satu aspek perkembangan saja yang akan berkembang tetapi semua aspek perkembangannya akan berkembang dengan baik. Karena pada masa ini adalah dimana masa yang paling awal untuk mengembangkan seluruh aspek perkembangan kepada anak.

Pendidikan anak usia dini (PAUD) adalah pendidikan yang memberikan pengasuhan, perawatan, dan pelayanan kepada anak usia lahir sampai enam tahun. Pendidikan anak usia dini merupakan wahana yang sangat fundamental dalam memberikan karangka dasar berbentuk dan perkembanganya dasar-dasar pengetahuan, sikap, dan pengetahuan pada anak. Dengan adanya pendidikan anak usia dini untuk mempersiapkan anak dengan memperkenalkan berbagai pengetahuan, sikap maupun perilaku kepada anak-anak dengan cara menyenangkan, karena pendidikan anak usia dini adalah tempat bermain yang nyaman. Ditempat inilah anakanak merasa tempat yang sangat indah serta nyaman untuk tempat belajar sambil bermain, berserta dapat bersosialisai dengan teman sebayanya. Dari sinilah pembentukan sikap dan karakter beserta mengembangkan aspek-aspek perkembangan anak. Dunia anak adalah dunia bermain dimana anak belajar sambil bermain, karena mereka adalah individu yang unik, mereka paling menyukai hal- hal yang kongkrit dan hal-hal yang baru. Karena dunia anak adalah dunia yang penuh dengan canda tawa dan kegembiraan sehinngga orang dewasa akan ikut terhibur dengan melihat tingkah pola mereka.

Pendidikan anak usia dini merupakan pendidikan formal sebelum anak masuk sekolah dasar, lembaga ini dianggap penting kerena bagi anak usia dini merupakan goldenage ( masa emas ) didalamnya terdapat " masa peka " yang hanya datang sekali dan tidak dapat diulang kembali anak usia dini berada dalam masa keemasan di sepanjang rentang usia perkembangan manusia. Pada masa itu anak berada pada masa priode sensitif (sensitive periods) dimana ini anak secara khusus muda menerima berbagai stimulus dari lingkungannya. Anak merupakan generasi penerus yang harus di berikan stimulasi yang sangat baik dalam tahap pertumbuhan dan perkembangannya, dimana anak harus di berikan pendidikan sejak dini untuk mengoptimalkan semua aspek perkembangan yang ada pada diri anak. Karena anak yang di stimulasikan dengan baik maka bukan hanya satu aspek perkembangan saja yang akan berkembang tetapi semua aspek perkembangannya akan berkembang dengan baik karena pada masa ini adalah dimana masa yang paling awal untuk mengembangkan seluruh aspek perkembangan kepada anak.

Anak tuna grahita merupakan salah satu klasifikasi anak berkebutuhan khusus (ABK) dengan hambatan di bidang mental. Hambatan mental yang dialami anak tuna grahita sering membuat mereka tidak dapat mengolah informasi yang diperoleh sehingga tidak dapat mengikuti perintah dengan baik. Anak tuna garahita memiliki kemampuan akademis dibawah rata-rata yang menyebabkan mereka tidak dapat berkembang sesuai dengan tahapan perkembangan pada usianya selayaknya anak-anak normal. Hal inilah yang menyebabkan anak tunagrahita memerlukan perhatian yang lebih dibandingkan dengan anak-anak normal lain. Diperlukan bimbingan dan perhatian dari guru atau pembimbing agar tingkat perkembangan diri anak yang bersangkutan dapat tercapai sesuai dengan keberadaannya. Hambatan intelektual pada anak tuna grahita tentu sangat berpengaruh pada kemampuan akademiknya. Anak tuna grahita tidak dapat disamakan kemampuannya dengan 
anak seusianya. Kemampuan anak tuna grahita berada jauh dibawah rata-rata mengingat anak tuna grahita juga memiliki IQ dibawah normal.

Karakteristik dari anak tuna grahita, dan ketersediaan sumber (sarana dan prasarana). Strategi yang dapat digunakan untuk pembelajaran bagi anak tuna grahita adalah strategi yang diindividualisasikan, kooperatif, dan modifikasi tingkahlaku. Pendekatan pembelajaran bagi anak tunagrahita juga memerlukan berbagai pertimbangan berdasarkan karakteristik dari anak tersebut. Pendekatan yang cenderung digunakan dalam pembelajaran bagi anak tunagrahita adalah dengan pendekatan modifikasi tingkahlaku. Hal ini dikarenakan perkembangan tingkahlaku pada anak tuna grahita banyak mengalami hambatan, sehingga tingkahlaku yang dikembangkan harus dapat diukur dan diamati. Pembelajaran bagisiswa tuna grahita di sekolah inklusi bertujauh berbeda dengan pembelajaran yang ada pada SLB. Selain pada sarana dan prasarana, perbedaan ini terdapat juga pada kemampuan guru. Guru di SLB tentu lebih berkompeten dalam mendidik anak berkebutuhan khusus.

Anak tuna grahita sering mengalami kesulitan dalam menyerap informasi, bahkan informasi sederhana yang termasuk mudah bagi orang normal. Pada anak tuna grahita hambatan yang dialami bukan hanya dalam hal akademiknya saja, tapi juga dalam pengelolaan emosi, pada anak tuna grahita sering mengalami gangguan emosi dan masalah-masalah perkembangan emosi sehubungan dengan kemampuannya yang rendah Hambatan intelektual yang dialami oleh anak tuna grahita menyebabkan perasaaan frustasi sehingga perkembangan emosi mereka menjadi ikut terhambat. Emosi pada anak tuna grahita sering tidak terkontrol dan meledak-ledak. Dalam beberapa kasus anak tuna grahita ada yang terlalu agresif adapula yang sangat tertutup, emosi yang kompleks inilah yang menyebabkan mereka kesulitan dalam bersosialisasi dengan orang lain. Berdasarkan hambatanhambatan yang dialami oleh anak tunagrahita, pembelajaran yang diterapkan tidak dapat disamakan dengan anak normal pada umumnya. Dalam menentukan strategi yang efektif guru harus memperhatikan tujuan pelaksanaan pembelajaran.

Tunagrahita ringan sering disebut juga moron atau debil. Menurut Skala Binet, sekelompok ini memiliki IQ antara 68-52, sedangkan menurut skala Weschler (WISC) memiliki IQ antara 69-55 anak tunagrahita masih dapat belajar membaca, menilis, dan berhitung sederhana. Dengan bimbingan dan didikan yang baik, anak tunagrahita ringan anak dapat memperoleh penghasilan untuk dirinya sendiri.

Berdasarkan kenyataan dilapangan, khususnya pada lembaga pendidikan anak usia dini dalam kegiatan kolase masih tergolong jarang dilakukan terutama pada lembaga PAUD maka pada saat itulah, Tujuan dari kajian literature ini adalah untuk mengembangkan kemampuan motorik halus anak dengan kegiatan kolase sehingga dapat mengembangkan kemampuan motorik halus anak tuna gtahita ringan sehingga dengan adanya kegiatan kolase dapat mengembangkan motorik halus anak, Karena dengan kegiatan kolase maka anak dapat melatih gerakan koordinasi tangan dan mata yang sudah baik maka anak sudah dapat melakukan kegiatan motorik halus seperti menulis, melipat, menggunting, menjepit, melukis dan sebagainya.

Perkembangan motorik halus pada anak usia dini merupakan perkembangan yang sangat penting untuk anak. Karena dari gerakan motorik halus anak dapat melatih gerakan koordinasi antara tangan dan mata. Dengan koordinasi tangan dan mata yang sudah baik maka anak sudah dapat melakukan kegiatan motorik halus seperti melipat, menggunting, menjepit, melukis dan sebagainya. Setiap anak mampu mencapai tahap perkembangan motorik halus yang optimal apabila mendapatkan stimulasi yang tepat. Perkembangan motorik halus pada anak usia dini merupakan perkembangan yang sangat penting untuk anak. Karena dari gerakan motorik halus anak dapat melatih gerakan koordinasi antara tangan dan mata 
Kolase adalah kreasi aplikasi yang menggabungkan teknik melukis (likisan tangan) dengan menempel bahan-bahan tertentu. Kolase suatu teknik menempel berbagai macam cat, seperti kertas, train, kaca, logam dan lain sebagainya kemudian dikombinasikan dengan penggunaan cat atau teknik lain.

Kolase merupakan salah satu kegiatan untuk mengembangkan kemampuan motorik halus anak. Dengan kegiatan kolase yang dilakukan oleh anak harus memiliki kesabaran yang luar biasa, dalam diri anak agar dapat menghasilkan suatu karya yang menarik yang dilakukan oleh anak dari sebuah butiran-butiran kecil yang di hubungkan menjadi karya seni yang indah. Bentuk Warna- warna yang indah juga dapat menarik perhatian anak dan menimbulkan rasa ingin tahunya tentang kegiatan kolase. Kegiatan kolase ini bertujuan untuk melatih koordinasi mata dan otot-otot tangan serta dapat berkonsentrasi karena kolase itu bersumber dari hati. Dengan adanya kegiatan kolase anak dapat mengembangkan aspek fisik motorik halusnya.

Karena Setiap anak memiliki karakteristik perkembangan yang berbeda-beda, yaitu dalam proses utama perkembangan anak. Adapun manfaat dalam kegiatan kolase tidak hanya dari aspek keterampilan saja, tetapi juga bermanfaat bagi perkembangan kognitif anak. Kegiatan kolase bagi anak juga bisa membantu melatih konsentrasi anak serta dapat melatih kesabaran anak. Selain itu anak juga akan lebih dari mengenal salah satu warisan budaya bangsa. Adapun kolase yang dapat dikenalkan pada anak usia dini dalam kegiatan ini adalah dengan kegiatan yang sederhana dan aman bagi anak yaitu dibuat dengan menjiplak pola-pola dan bentuk kegiatan kolase yang sudah terbentuk dengan cara menempel dalam hal ini anak bebas menuangkan ide dan kreatifnya untuk mendapatkan hasil yang diiginkan. Alat yang dapat digunakan yaitu kertas putih, lem, gunting daun atau biji-bijian (bentuk sesuai keinginan). Adapun cara pengunaannya yaitu anak menjiblak terlebih dahulu pola yang akan dibentuk dengan pensil atau spidol warna dengan bantuan yang diinginkan anak setelah anak memenempel titik-titik pola yang sudah dibentuk sehingga menjadi karya indah. Betapa bahagia mereka saat bermain dengan bermacam macam permainan yang mereka sukai serta dapat mengenal berbagai warna yang diterapkan pada saat melakukan kegiatan kolase. Kegiatan anak usia dini tidak lepas dari kegiatan fisik motorik, dimana fisik motorik mencakup motorik halus dan motorik kasar. Motorik halus merupakan kemampuan anak untuk melakukan kegiatan yang melibatkan koordinasi mata, tangan dan otot-otot kecil pada jari-jari, pergelangan tangan dan lengan yang digunakan untuk aktivitas seni. Sedangkan motorik kasar merupakan koordinasi gerakan tubuh pada anak seperti merangkak, berlari, berjinjit, melompat, bergantung, melempar dan menangkap,serta menjaga keseimbangan tubuh. Salah satu potensi yang perlu dikembangkan sejak dini pada anak usia dini yaitu tentang keterampilan motorik halus dengan kegiatan kolase.

Dengan kegiatan kolase maka anak dapat melatih dengan mengembangkan kemampuan motorik halusnya. Gerakan koordinasi tangan dan mata yang sudah baik maka anak sudah dapat melakukan kegiatan motorik halus seperti menulis, melipat, menggunting, menjepit, melukis, dan sebagainya. Setiap anak yang mampu mencapai tahap perkembangan motorik halus yang optimal apabila mendapatkan stimulasi yang tepat. Oleh karena itu untuk mengoptimalkan pertumbuhan dan perkembangan anak dalam mengembangkan kemampuan motorik halus dengan pendekatan seni yang merupakan suatu proses pembelajaran yang dapat meningkatkan keterampilan motorik halus anak. Ada beberapa permasalahan pada anak tuna grahita ringan, yang pertama yaitu permasalahan pada motorik halusnya sehingga menyebapkan anak sulit untuk memegang pensil atau spidol warna, yang kedua terdapat pada fisik, yang ketiga terdapat pada kedisiplinan, yang difokuskan hanya pada motorik halus yang kurang berkembang, sehingga terhambat pada proses menulis sehingga peneliti memilih dengan mengangkat judul, Meningkatkan kemampuan motorik halus dengan kegiatan 
kolase sebagai persiapan menulis anak tuna grahita ringan. Karena dengan kegiatan kolase maka anak dapat melatih gerakan koordinasi tangan dan mata yang sudah baik maka anak sudah dapat melakukan kegiatan motorik halus seperti menulis, melipat, menggunting, menjepit, melukis dan sebagainya.

Berdasarkan kenyataan dilapangan, khususnya pada lembaga pendidikan anak usia dini dalam kegiatan kolase masih tergolong jarang dilakukan terutama pada anak tuna grahita maka pada saat itulah, Tujuan dari kajian literature ini adalah untuk manfaat sesuatu kajian tentang kemampuan motorik halus anak dengan kegiatan kolase sehingga dapat mengembangkan kemampuan motorik halus sebagai persiapan menulis anak tuna grahita ringan.

B. Pembahasan.

\section{Motorik Halus.}

Menurut Sumantri dalam yulianto dan Dkk (2017:120) menyatakan bahwa motorik halus adalah pengorganisasian penggunaan sekelompok otototot kecil seperti jari- jemari dan tangan yang sering membutuhkan kecermatan dan koordinasi dengan tangan, memerlukan koordinasi yang cermat. Keterampilan motorik halus (fine motor skill) merupakan keterampilan yang, memerlukan untuk mengontrol otot-otot kecil/halus untuk mencapai pelaksanaan keterampilan yang berhasil. Pengembangan keterampilan motorik halus akan mempengaruhi terhadap kesiapan anak dalam proses belajar disekolah serta membuat akan lebih mandiri. Kegiatan melati koordinasi antara mata dengan tangan ini dapat dilakukan dengan menempel, menggunting dan lain-lain. Dalam upaya peningkatan gerak motorik halus pada siswa tunagrahita tidak terlepas dari penggunaan media pembelajaran yang tepat. Salah satu terobos media pembelajaran yang menarik. Sedangkan menurut Lindya dalam Aida fitri dkk (2018:53) menyatakan bahwa motorik halus yaitu aspek yang berhubungan dengan kemampuan anak untuk melakukan gerakan pada bagian-bagian tubuh tertentu saja dan dilakukan oleh otot-otot kecil tetapi memerlukan koordinasi yang cermat. Keterampilan motorik halus (fine motor skill) merupakan keterampilan yang. Memerlukan kemampuan untuk mengontrol otot-otot kecil/halus untuk mencapai pelaksanaan keterampilan yang berhasil. Pengembangan keterampilan motorik halus akan berpengaruh terhadap kesiapan anak dalam proses belajar disekolah serta membuat anak lebih mandiri.

Gerak motorik halus adalah gerakan yang hanya melibatkan bagian-bagian tubuh tertentu saja yang dilakukan oleh otot-otot kecil, seperti ketrampilan menggunakan jari jemari tangan dan gerakan pergelangan tangan yangtepat. Oleh karenaitu, gerakan initidak terlalu membutuhkan tenaga, Gerakan ini membutuhkan koordinasi matadan tangan yang cermat. motorik halus adalah pengorganisasian penggunaan sekelompok otot-otot kecil seperti jari-jemari dan tangan yang sering membutuhkan kecermatan dan koordinasi dengan tangan, ketrampilan yang mencakup pemanfaatan menggunakan alat-alat untuk mengerjakan suatu objek. Oleh karena koordinasi antara mata dan tangan sudah semakin baik makaanak sudah dapat mengurus diri sendiri dengan pengawasan orang yang lebih tua. Gerakan motorik halus yang terlihat pada anak usia TK antara lain adalah: Anak dapat menyikat gigi sendiri, menyisir, membuka menutup retsluiting, memakai sepatu sendiri, makan sendiri. Semakin baiknya gerakan motorik halus anak membuatnya lebih mandiri, akan tetapi tidak semua anak memiliki kematangan untuk menguasai kemampuan ini pada tahap yang sama (Sumantri 2005:143).

Menurut Danim (2014: 47) mengatakan bahwa keterampilan motorik (motorik skills) terdiri dari dua jenis, yaitu keterampilan kasar (gross motorik skills) dan keterampilan halus (fine motorik skills) keterampilan motrik adalah 
kemampuan fisik atau keterampilan motorik kasar yang meliputi perjalanan, berlompat, meloncat, berputar, melempar, menyeimbangkan, dan menarik yang melibatkan penggunaan gerak tubuh besar. keterampilan motorik halus yaitu gerakan-gerakan yang merupakan hasil koordinasi otot-otot yang menuntut adanya kemampuan mengontrol gerakan-gerakan halus. Gerakan motorik halus pada anak berkaitan dengan kegiatan meletakkan, atau memegang suatu objek dengan menggunakan jari (Mursid, 2015:12).

Menurut Yudha M. Saputr adalam Setia (2015:3)menyatakan bahwa perkembangan motorik adalah suatu perubahan dalam perilaku motorik yang memperhatikan interaksi dari kematangan mahluk dan lingkunagnnya motorik merupakan perubahan kemampuan motorik dari bayi sampai dewasa yang melibatkan berbagai askep perilaku dan kemampuan motorik. Aspek perilaku dan perkembangan motorik saling mempengaruhi satu sama lain.

Motorik halus merupakan perkembangan gerak fisik seorang individu yang meliputi otot kecil serta koordinasi seimbang antara mata dengan tangan. Gerakan motorik ini dilakukan secara bertahap dengan adanya stimulasi oleh orang tua dan pendidik. Menggerakan jari jemari yang seimbang pemikiran serta koordinasi mata membuat gerakan motorik halus ini menghasilkan keterampilan khusus sehingga seseorang mampu berkreasi menciptakan raga hiasan mungil, lukisan atau sekedar tulisan tangan yang teratur rapi dan cantik (Murtie, 2017: 179-180).

Perkembangan motorik halus melibatkan otot-otot yang mengendalikan tangan dan kaki. Kemampuan anak dalam mengontrol, mengkoordinasikan dan ketangkasan dalam menggunakan tangan dan jemari, adalah menjadi focus dari perkembangan motorik halus anak. Meskipun perkembangan berlangsung secara bersamaan dengan perkembangan motorik kasar, namun otot-otot dekat batang tubuh matang sebelum otot-otot kaki dan tangan yang mengendalikan pergelangan dan tangan. Oleh karena itu, penting bagi anak untuk berlatih menggunakan otot-otot besar saat terlihat dalam kegiatan kegiatan motorik halus (Novi Mulyana, 2018: 30).

Perkembangan motorik halus adalah proses sejalan dengan bertambahnya usia secara bertahap dan berkesinambungan gerakan individu meningkatkan dari keadaan sederhana, tidak terorganisasi, dan tidak terampil kearah penampilan keterampilan motorik yang kompleks dan terorganisasi dengan baik yang pada akhirnya kearah penyesuaian keterampilan menyertai terjadinya proses manusia atau menjadi tua (Sumatri, 2005: 47).

Perkembangan motorik berkembanga sejak dengan kematangan syaraf dan otot. Oleh karena itu, setiap gerakan yang dilakukan oleh anak sederhana apapun sebenarnya merupakan hasil pola interaksi kompleks dari berbagai dan sistem didalam tubuh yang mengontrol otak (Saptiana, 2018:22). Sedangkan menurut Suyadi dan Laura. E dalam Ardy (2005:31), menyatakan bahwa gerakan motorik halus adalah meningkatkan, pengkoordinasian gerak tubuh yang melibatkan kelompok otot dan syaraf kecil lainya. Gerakan motorik halus merupakan keterampilan menggunakan media dengan koordinasi antara tangan dan mata.

Tujuan peningkatan motorik halus di antaranya adalah: saat anak mengembangkan kemampuan motorik halusnya diharapkan anak dapat menyesuaikan lingkuangan sosial dengan baik serta menyediakan kesempatan untuk mempelajari keterampilan sosialya karena setiap pengembangan tidak dapat terpisah satu sama lain. Meningkatkan motorik halus anak agar mampu mmengembangkan keterampilan motorik halus khususnya koordinasi mata dan 
tangan secara optimal. Semakin banyak anak melakukan sendiri suatu kegiatan maka semakin besar juga rasa kepercayaan dirinya (Setia 2015: 03)

Selanjutnya fungsi motorik halus pada anak, menurut Paraswati (2013:19) menyatakan bahwa fungsi perkembangan kemampuan motorik halus anak mendukung aspek pengembangan lainnya seperti kognitif dan bahasa serta sosial karena pada hakekatnya setiap pengembangan tidak dapat terpisah satu sama lain. Fungsi gerak motorik halus adalah meningkatkan pengkoordinasian gerakan tubuh yang melibatkan otot dan syaraf yang jauh lebih kecil atau detail. Kelompok otot dan syaraf inilah yang nantinya mampu mengembangkan gerak motorik halus seperti merema kertas, menyobek, menggambar, menempel, menulis, dan sebagainya. Pada anak usia dini perkembangan motorik halus dikembangkan dengan sebaik-baiknya (Septiana, 2018:22).

\section{Kegiatan Kolase.}

Menurut Susanto dalam Madiarti (2013:12) kolase dalam bahasa inggris "collage" berasaldari kata "coller" yang artinya merekat. Selanjutnya kolase dipahami sebagai suatu teknik menempel berbagai macam materi, selain cat, seperti kertas, kain kaca, logam dan lainya. Sebagian dikombinasi dengan cat (minyak) atauteknik yang lainya. Kolase dapat rekat dengan berbagai jenis permukaan, seperti kayu, plastik, kertas, kaca dan sebagainya untuk dimanfaatkan atau difungsikan sebagai benda fungsional atau karya seni.

Menurut Kasim dalam Madiarti, Efis (2013:12-13) kolase adalah menggambar teknik tempelan. Sedangkan Muharam (1992:84 ) menyatakan bahwa kolase adalah teknik melukis dan mempergunakan warna-warna keeping batu, kaca, marmer, keramik, kayu, yang ditempelkan. Kolase merupakan bentuk ganbar dan diwujutkan dengan menyusun keeping berwarna yang diolesi lem kemudian kemudian ditempelkan pada bagian gambar.

Kolase sebagai komposisi artistik yang dibuat dari berbagai bahan yang ditempelkan pada pemukaan gambar. Dalam kegiatan kolase bentuk asli gambar masi bisah dikenali walaupun sudah ditempel dengan robekan-robekan kertas, biji-bijian, daun kering, ataupun yang lainya. Kegiatan kolase pada anak usia dini dengan menggunakan media kertas diawali dengan merobek kertas kemudian dilem, direkatkan pada kertas dan dipadukan dengan unsur gambar. Selain dengan kertas kegiatan mengisi kolase juga dapat menggunakan bahan-bahan bekas atau daurualang, biji-bijian seperti kacang hijau, beras, kedelai. Berkreasi dengan beragam benda-benda bekas atau bahan daurualang akan menghasilkan kreativitas anak, anak didorong untuk bereksplorasi dan menemukan solusi yang kreatif sesuai usia anak (Siti Amsoh,2016: 3).

Menurut Novi Muliyana Dalam Nurkhasanah (2019:8) menyatakan bahwa kegiatan menempel atau kolase ini menarik minat anak-anak karena mereka bias meletakan dan merekatkan sesuatu sesuka mereka. Senada dengan hal tersebut, kolase dengan produknya yang cepat dan bermotif, berefek tiga dimensi adalah kesukaan anak-anak usia 3-6 tahun. Berbagai macam benda dapat digunakan untuk membuat kolase. Bahan-bahan ringan bisa ditempelkan pada kertas biasa atau karton.

Menurut Mayesky dalam Fitri Aida (2018:53) menyatakan bahwa kolase bertujuan untuk mengembangkan kreativitas, mengembangkan motorik halus, kordinasi tangan dan mata, mengeksplorasi kegunaan baru dari berbagai macam kertas dan mempelajari tentang konsep-konnsep desain dari pola, penempatan, ukuran dan bentuk. Kolase memiliki unsur-unsur senirupa lain, yaitu unsure seni lukis dari bentuk tiga dimensi yang datar dan menggambarkan suatu bentuk tetapi diwakili oleh benda yang bermacam-macam sebagai pengganti garis, warna 
dan bidangnya. Garis warna dan bidang sebagai unsure seni lukis yang kedudukannya diganti oleh barang-barang atau material sebagai unsure kolase.

Adapun manfaat dari kegiatan kolase untuk anak adalah dapat mengembangkan kemampuan anak dalam mengkoordinasi mata dan tangan serta dapat mengerakkan otot-otot tangan agar dapat berkembang secara optimal Mayesky dalam Fitri Aida (2018:53) Manfaat kegiatan kolase akan dapat meningkatkan kreativitas anak yaitu dapat berkreasi memilih bahan, menyusun warna, kontur, dan memadukannya sesuai selera sehingga menghasilkan karya yang indah, melatih motorik halus anak yaitu melatih keterampilan jari-jemari anak, melatih konsentrasi anak, anak dapat mengenal warna dan memadukannya sesuai selera, anak dapat mengenal bentuk dari pola-pola yang ia tempel atau ia gunting, anak dapat mengenal aneka jenis bahan dalam melakukan teknik kolase, mengenal sifat bahan yang disediakan, dan melatih ketekunan serta kesabaran dalam melakukan teknik kolase sehingga menghasilakan suatu karya yang menarik. Angriani Saragih (2019-25).

Ada beberapa manfaat dari kolase adalah sebagai berikut :

a. Menstimulus kemampuan motorik halus anak.

b. Dapat meningkatkan kreativitas anak,

c. Dapat melati kosentrasi anak,

d. Anak dapat mengenal warna dan menambahkan kosa kata bagi anak,

e. Anak dapat mengenal bentuk geometrik dan yang bukan geometris,

f. Melati anak untuk menyelesaikan masalah lewat permainan kolase,

g. Mengasah kecerdasan special anak,

h. Melatih ketekunan pada anak,

i. Meningkatkan kepercayaan diri pada anak.

Manfaat kegiatan kolase untuk anak adalah dapat mengembangkan kemampuan anak dalam mengkoordinasi mata dan tangan serta dapat menggerakan otot-otot tangan agar dapat berkembang secara optimal.

Alat dan bahan yang digunakan dalam kegiatan kolase yaitu:

a. Kertas hvs/kertas gambar.

b. Lem fox/lem kertas.

c. Gunting.

d. Pensil.

e. Bahan alam/ daun kering.

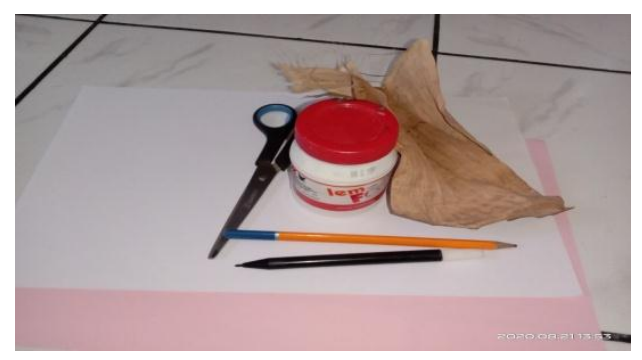

Gambar 1. Alat dan Bahan.

Cara yang dilakukan dalam kegiatan kolase ini:

a. menyiapkan alat untuk membuat kolase, menjelaskan kepada anak-anak tentang alat dan bahan yang akan digunakan membuat kolase.

b. Membagi anak dalam kelompok kecil.

c. Mulai membuat bentuk atau pola dan motif kolase.

d. Mulai meletakan lem dan memasangkan bahan-bahan lainya. 


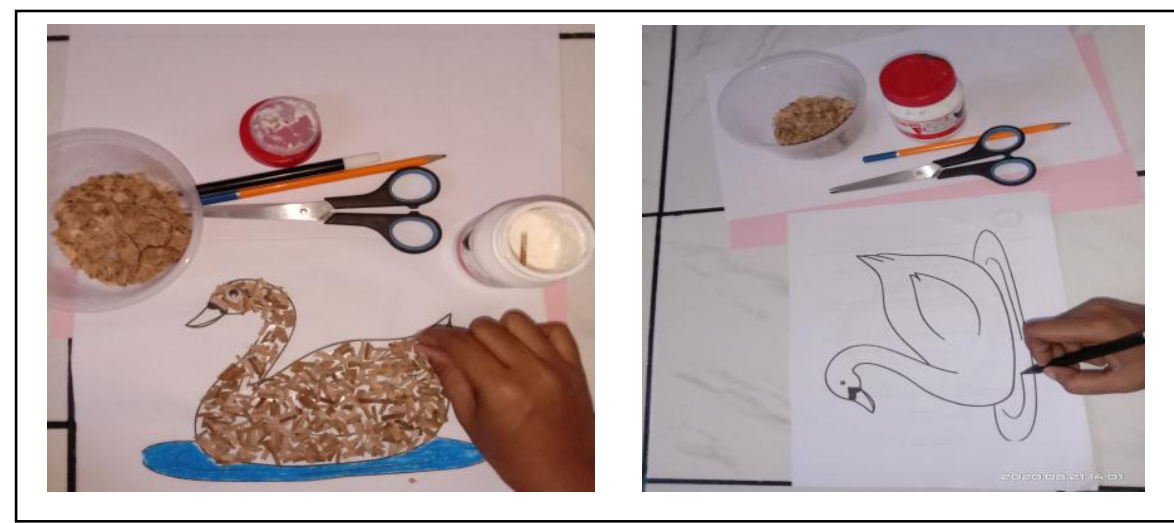

Gambar 2. Cara membuat kolase.

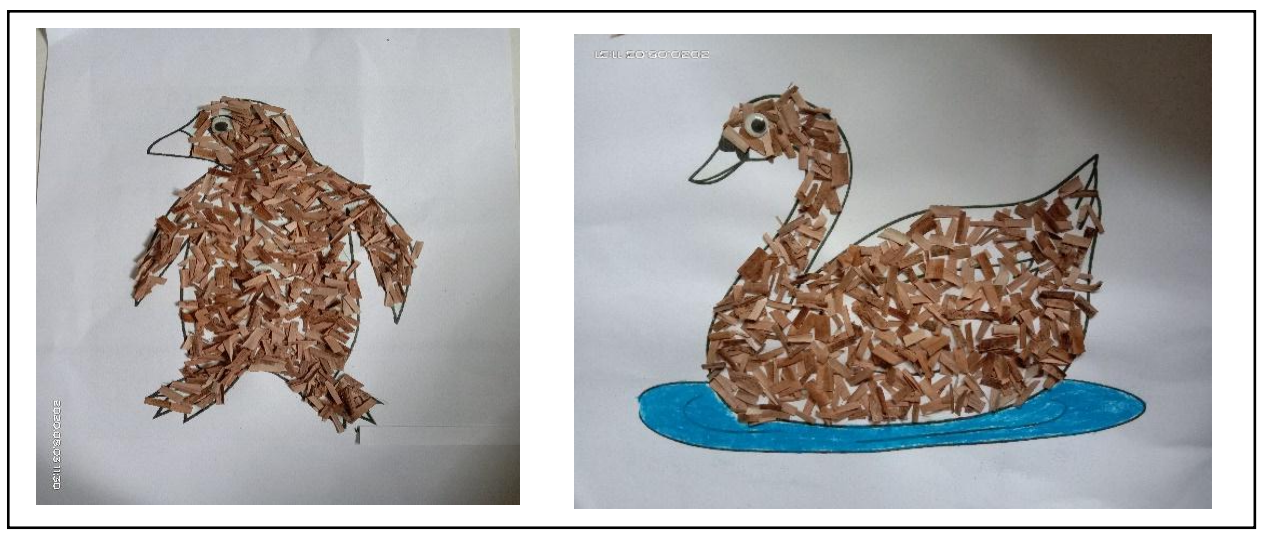

Gambar 3. Kreasi kegiatan kolase.

Kelebihan dalam melakukan kegiatan kolase sebagai berikut:

a. Anak terlibraat seca langsung dalam pembelajaran.

b. Kegiatan kolase dapat mengembangkan beberapa aspek yaitu aspek fisik motorik halus, aspek kognitif, dan serta aspek seni.

c. Anak mengenal berbagai warna sehingga menimbulkan rasa ingin tahu anak dalam kegiatan kolase.

d. Anak juga bias berkonsentrasi dan melatih kesabaran dan selain itu juga anak akan lebih mengenal salah satu budaya Indonesia yaitu dengan cara kolase.

Kelebihan dalam melakukan kegiatan kolase sebagai berikut: yang pertama yaitu anak terlibat secara langsung dalam pembelajaran. Kedua kegiatan kolase dapat mengembangkan beberapa aspek yaitu aspek fisik motorik halus, aspek kognitif, dan serta aspek seni. Dan yang ketiga anak mengenal berbagai warna sehing ga menimbulkan rasa ingin tahu anak dalam kegiatan kolase. Selanjutnya yang keempat anak juga bisa berkonsentrasi dan melatih kesabaran dan selain itu juga anak akan lebih mengenal salah satu kegiatan anak indonesia yaitu dengan membuat kegiatan kolase.

Kolase dalam penelitian ini adalah merupakan suatu kegiatan yang teknik berolah seni rupa yang akan menggabungkan teknik melukis (menggabar dengan tangan) dengan keterampilan menyusun dan merekatkan bahan-bahan pada kertas gambar atau bidang dasar yang digunakan, sampai yang dihasilkan tatanan yang unik, menarik dan berbeda menggunakan bahan kertas, bahan alam dan bahan bekas. Dalam melakukan teknik kolase anak usia dini dapat memanfaatkan apa yang ada dilingkungan dan didalam bumi (bahan alam) seperti dedaunan, biji-bijian, bebatuan ranting dan sebagainya. Kegiatan ini dapat membuat otot-otot halus anak atau disekitar jari jemari anak berfungsi ketika anak memegang, dan 
menuangkan ada gerakan-gerakan disana semakin anak melakukan berulangulang tangan anak atau otot-otot halus anak akan berkembang dan itu sebagai modal untuk anak menulis permulaan.

\section{Pengertian anak tuna grahita.}

Tuna grahita adalah suatu kondisi anak yang kecerdasannya jauh di bawa rata-rata dan ditandai oleh keterbatasan intelegansi dan ketidak cakapan dalam komunikasi sosial. Anak berkebutuhan khusus ini juga sering dikenal dengan istilah terbelakang mental karena keterbatasan kecerdasanya. Akibatnnya anak berkebutuhan khusus ini sukar untuk mengikuti pendidikan disekolah bias (jati rinakri atmaja 2018: 98).

Menurut Muljono dalam Aida Firti, dkk (2018 : 53). Tunagrahita adalah kata lain dari retardasi mental (mental retardation), yang arti harfiahnya dari perkataan tuna yang artinya merugi sedangkan grahita artinya pikiran. Tunagrahita ditandai oleh kelemahan dalam berpikir dan bernalar, akibatnya anak memiliki kemampuan dan belajar dan adaptasi sosial berada di bawah rata-rata". Pada siswa tunagrahita keterampilan motorik halus sangat diperlukan dalam melakukan aktivitasnya sehari-hari yang mengharuskan mereka untuk belajar lebih mandiri dan tidak terus bergantung kepada orang lain. Hampir sepanjang hari peserta didik di sekolah menggunakan keterampilan motorik halus untuk kegiatan akademiknya, termasuk dalam menulis, memegang gunting, menempel dan masih banyak lagi.

Menurut Dudi Gunwan (2011) anak gangguan intelektual (Tunagrahita) adalah anak yang secara nyata mengalami hambatan dan keterbelakangan perkembangan mental-intelektual di bawah rata-rata, sehingga mengalami kesulitan dalam menyelesaikan tugas-tugasnya. Mereka memerlukan layanan pendidikan khusus. Tunagrahita ialah istilah yang digunakan untuk menyebut anak yang mempunyai kemampuan intelektual di bawah rata-rata. Berbagai istilah yang dikemukakan mengenai tunagrahita, selalu menunjuk pada keterhambatan fungsi kecerdasan secara umum berada di bawah usia kronologisnya secara meyakinkan sehingga membutuhkan layanan pendidikan khusus. Potensi dan kemampuan setiap anak tunagrahita berbeda-beda, maka untuk kepentingan pendidikan diperlukan pengelompokkan anak tunagrahita. Pengelompokkan itu berdasarkan berat ringannya ketunaan, atas dasar itu anak tungrahita dapat dikelompokkan.

a. Tunagrahita Ringan Anak tunagrahita ringan pada umumnya tampang atau kondisi fisiknya tidak berbeda dengan anak normal lainnya, mereka mempunyai IQ antara kisaran $50 \mathrm{~s} / \mathrm{d} 70$. Mereka juga termasuk kelompok mampu didik, mereka masih bisa dididik (diajarkan) membaca, menulis dan berhitung, anak tunagrahita ringan biasanya bisa menyelesaikan pendidikan setingkat kelas IV SD Umum.

b. Tunagrahita Sedang Anak tunagrahita sedang termasuk kelompok latih. Tampang atau kondisi fisiknya sudah dapat terlihat, tetapi ada sebagian anak tunagrahita yang mempunyai fisik normal. Kelompok ini mempunyai IQ antara $30 \mathrm{~s} / \mathrm{d}$ 50. Mereka biasanya menyelesaikan pendidikan setingkat kelas 2 SD Umum.

c. Tunagrahita Berat Kelompok ini termasuk yang sangat rendah intelegensinya tidak mampu menerima pendidikan secara akademis. Anak tunagrahita berat termasuk kelompok mampu rawat, IQ mereka rata-rata 30 kebawah. Dalam kegiatan sehari-hari mereka membutuhkan bantuan orang lain.

Ketunagrahitaan mengacu pada intelektual umum yang secara signifikan berada di bawah rata-rata. Para tunagrahita mengalami hambatan dalam tingkah 
laku dan penyesuaian diri. Semua gangguan tersebut berlangsung atau terjadi pada masa perkembangannya. Lebih lanjut,

Anak tunagrahita adalah anak yang secara signifikan memiliki kecerdasan dibawah rata-rata anak pada umumnya dengan disertai hambatan dalam penyesuaian diri dengan lingkungan sekitarnya. Mereka memiliki keterlambatan dalam segala bidang dan itu sifatnya permanen. Rentang memori mereka pendek terutama yang berhubungan dengan akademik, kurang dapat berpikir abstrak dan pelik (Nunung Apriyanto, 2012: 21).

Efendi dalam Aida Firti, dkk (2018: 53). Mengemukakan bahwa anak tunagrahita ringan adalah anak tunagrahita yang tidak mampu mengikuti pada sekolah program biasa.Simpulan dari beberapa pendapat di atas adalah untuk mengetahui kemampuan motorik halus anak setelah penerapan kolase. Oleh sebab itu anak tunagrahita ringan membutuhkan pendidikan khusus, bimbingan khusus, latihan khusus, supaya mentalnya dapat berkembang dan tumbuh sampai optimal, termasuk dalam melatih kemampuangerakmotorikhalusnya, dengan menggunakan bahan bekas dan bahan alam. Berdasarkan tujuan penelitian, maka penulis tertarik mengangkat judul "Meningkatkan Kemampuan Motorik Halus dengan kegiatan kolase sebagai persiapan menulis anak tunagrahita ringan.

4. Penelitian relevan.

Berdasarkan hasil yang di dapat dari beberapa penelitian sebelumnya terkait dengan kegiatan membatik dalam mengembangkan kemampuan motorik halus anak oleh beberapa penelitian sebagai berikut.

Beberapa hasil penelitian yang telah melakukan penelitian tentang mengembangkan kemampuan motorik halus anak. Penulis menemukan penelitian yang dilakukan oleh Yulianto Dema dan dkk (2017), dengan judul "Meningkatkan Kemampuan Motorik Halus Melalui Kegiatan Kolase Pada Anak Kelompok B RA AlHidayahnanggung an Kecamatan Prambo Kabupaten Nganjuk". Subjek dalam penelitian ini berjuml 30 anak terdiri dari 13 anak laki-laki dan 17 anak perempuan RA AL-HIDAYAH Nanggungan Kecamatan Prambon Kabupaten Nganjuk pada anak kelompok B. Metode yang digunakan adalah penelitian tindakan kelas (PTK) yang dilaksanakan selama 3 siklus, disetiap pertemuan dilaksanakan selama tiga kali pertemuan. Teknik analisis data dalam penelitian ini menggunakan dekskriptif kualitatif. Tujuan dari penelitian ini adalah untuk meningkatkan kemampuan motorik melalui aktivitas kekuatan media pada RA ALHIDAYAH Nanggungan Kecamatan Prambon Kabupaten Nganjuk pada anak kelompok B. Hasil penelitian ini Dalam penelitian ini terbukti bahwa kegiatan pembelajaran kolase menggunakan pengembangan daya media pada siklus I mencapai skor rata-rata menunjukkan bahwa prosentase kemampuan motorik halus anak melalui kegiatan kolase meningkat dari pra siklus 20\%, siklus I 58,3\% dan pada siklus II sebesar $80 \%$. Demikian juga dari hasil observasi guru juga menunjukkan hasil yang meningkat dari $62,5 \%$ menjadi $87,5 \%$ pada siklus II. Sehingga dapat dikatakan kegiatan berjalan dengan baik dan sudah memenuhi kriteria ketuntasan minimal sebesar $75 \%$. Brarti tindakan guru dalam meningkatkan kemampuan motorik halus pada anak kelompok B RA ALHIDAYAH Nanggungan kecamatan Prabon Kabupaten Nganjuk . dengan penguasaan klasik $87,5 \%$ yang dikategorikan kriteria baik.

Selanjutnya hal sama dilakukan oleh peneliti, RatnaFaeruz, Dan Dkk ( 2019 ) juga melakukan penelitian dengan judul"Permainan Kolase Untuk Meningkatkan Kemampuan Motorik Halus Pada Kelompok A Tk Muslimat Nu Banjarmasi “ 
Penelitian ini menggunakan metode penelitian tindakan kelas (PTK) yang dilaksanakan dalam 2 siklus,setiap siklus terdiri 4 tahapan yaitu perencanaan, tindakan, observasi, refleksi. Subjek penelitiannya anak A Di Tk MuslimatNu Banjarmasidenganjumlahanaksebanyak 10 anakyang terdiri atas 5 anak laki-laki dan 5 anak perempuan.Metode pengumpulan data menggunakan wawancara, observasi dan dokumentasi. Hasil observasi kemampuan motorik halus dianalisis secara deksriptif kualitatif dan kuantitatif.Berdasarkan hasil analisis terbukti bahwa kemampuan motorik halus anak kelompok A mengalami peningkatan. Nilai rata-rata kemampuan motorik halus anak siklus 1 sebesar 11,14\% dan siklus 11 sebesar $29,09 \%$.

Hal sama dilakukan peneliti yang mirip oleh Madiati Eris Dan Ningtyas ( 2013 ) dengan judul "Peningkatan Kemampuan Motorik Halus Anak Melalui Kegiatan Kolase Dengan Menggunakan Media Berbentuk Bahan Alam Di Paud Melati Kabupaten Lebong" Penelitian ini menggunakan pendekatan penelitian tindakan kelas kelas (PTK), Teknik pengumpulan data yaitu hasil dari karya dan observasi. Data dianalisis dengan teknik deskriptif kuantitatif, yang dilaksanakan sebanyak 3 siklus peningkatan juga terjadi pada perkembangan anak yang mencapai ketuntasan, dimanasiklus 1 hanya 10 orang anak 43,5 \% yang dikategorikan cukupdan siklus II meningkat menjadi 19 anak 82,6\% yang dikategorikan baik. Beberapa hasil yang diperoleh, dapat disimpulkan bahwa pembelajaran kolase berbahan alam yang berlangsung dengan baik dapat meningkatkan kemampuan motorik halus anak.

Selanjutnya penelitain lain yang dilakukan oleh Annisa Septiana, dengan judul "Meningkatkan Kemampuan Motorik Halus Melalui Kegiatan Kolase Dengan Berbagai Media Di Tk Aisyiyah bustanul Aba Ngoro-Oro patuk gunung kidul Kelompok B3". Tujuan untuk mengembang kemampuan motorik halus anak melalui kolase, Penelitian ini menggunakan metode penelitian tindakan kelas (PTK) yang dilaksanakan dalam 2 siklus, setiap siklus terdiri empat komponen yaitu perencanaan, (plain), tindakan dan pengamatan (action dan observe), sertarefleksi (reflect). Sedangkan, pelaksanaan siklus kedua terdiri dari revisi perencanaan (resived plan) Subjek dalam penelitian ini adalah berjumlah 21 anak yang terdiri 12 anaklaki-laki dan 9 anak perempuan. Kondisi awal tindakan sebesar 23,80\% pada siklus 1 meningkat menjadi 61,90\% dan siklus II meningkat menjadi $100 \%$ pada siklus 1 dan siklus II telah memenuhi indicator keberhasilan 100\%. Dengan menerapkan kegiatan kolase pada Tk Aisyiyah bustanul Aba Ngoro-Oro patuk gunung kidul Kelompok B3. Telah berhasil meningkatkan kemampuan motorik halus dengan kegiatan kolase.

Selanjutnya penelitian yang dilakukan oleh Fitri Aida Dan Bahri Syaiful dengan judul "penggunaan media kolase untuk meningkatkan kemampuan gerak motorik halus siswa tuna grahita ringan di SDLB negeri banda aceh "tujuan dari penelitian ini adalah untuk meningkatkan kemampuan motorik halus anak tuna grahita ringan dengan menggunakan media kolase. Penelitian ini menggunakan metode campuran yang mendukung pendekatan kualitatif dan kuantitatif dalam hal metodologi. Sebjek penelitian ini terdiri dari 2 siswa anak tuna grahita ringan di SDLB negeri bandaacah. Adapun data yang dikumpulkan melaluiobserfasi dan wawancara, yang dimana obserfasi ini dilakukan dengan menggunakan tes pembuatan kolase yang diamati oleh pengamatan, tes dilakukan sebelum dan sesuda perlakukan diberikan. Selanjutnya dilakukan dengan wawancara dengan 
guru untuk memperoleh data yang lebih akurat, tindakan dalam penelitian ini dilakukan dalam 5 kali pertemuan, yang dimana pertemuan pertama yang didapatkan dalam skor aspek menjiblak pola yaitu (BSH), pertemuan kedua yang didapatkan dalam skor memegang daun dan biji-bijian dikategirikan (BSB), pertemuan ketiga dilihat dari anak menggunting bahan-bahan dan mendapatkan skor (MB) pertemuan keempat dilihat dari kemampuan menempel kolase dan mendapat skor (BSH). Dari hasil perhitungan dan posttes maka dapat disimpulkan bahwas ubjek yang memiliki keterbatasan dalam kemampuan gerak motorik halus setelah diterapkan dengan kegiatan kolase mengalami peningkatan, terlihat dari skor kemampuan gerak motorik halus yang diperoleh dari setiap individu. Pada mulanya setiap anak memiliki tingkat kemampuan motorik halus yang rendah dengan nilai 0 . Skor kenaikan kemampuan gerak motorik halus tertinggi pada anak mencapai skor 3 setelah diterapkan dan diperlakukan dalam kegiatan kolase.

Selanjutnya penelitain lain yang dilakukan oleh Ismatul Khasana, M. Kristanto, Dan Dian Puji Puspita. (2017). Dengan judul” peningkatan kreativitas seni kolase melalui keping geometri pada kelompok B TK aisyiyah bustahanul athfal 34 semarang tahun 2017" tujuan yang hendak dicapai dalam penelitian ini adalah untuk meningkatkan kreativitas seni kolase melalui keping geometri pada kelompok B TK aisya bustahanul athfal 34 semarang. Jenis penelitian ini adalah tindakan kelas (PTK). Populasi penelitian ini adalah seluruh siswa kelompok B TK Aisyiyah busthanul athafal34 semarang. Penelitian dilaksanakan pada semester 2 bulan mei sampai juni. Sampel penelitian yang diambil adalah sebanyak 8 siswa yang terdiri 7 anak laki-laki dan 8 anak perempuan. Data dalam penelitian ini yang diperoleh melalui dokumentasi dan obserfasi. Hasil analisis yang diperoleh dari awal penelitian ada 20\% (3 anak) dengan kategori baik, kemudian peneliti memberikan siklus kepada anak untuk meningkatkan kreasi seni kolase. Siklis 1 mengalami peningkatan mencapai 33,33\% (5 anak ) dari 15 anak dengan kategori baik, karena belum berhasil maka diberikanlah siklus II. Siklus II memberikan kenaikan sebesar 86,67\% (13 anak ) dengan kategori baik dan dapat dikatakan penelitian ini berhasil 66\% sehingga tdk perlu melanjutkan siklus III. Dengan menerapkan kereativitas seni kolase melalui keping geometri pada kelompok B TK Aisyaiyah bustahanul athfal 34 semarang.

Juniyanasari (2015) melakukan penelitian dengan hasil penelitian menunjukkan bahwa pada siklus I rata-rata persentase keterampilan motorik halus adalah $69,79 \%$ berada pada katagori sedang, sedangkan terjadi peningkatan pada siklus II menjadi $80,99 \%$ dengan katagori tinggi, hal tersebut menandakan bahwa terdapat peningkatan rata-rata persentase keterampilan motorik halus pada anak kelompok B PAUD ABC Singaraja pada siklus I dan siklus II sebesar $11,2 \%$. Jadi penerapan pembelajaran kontekstual melalui cooking class dapat meningkatkan keterampilan motorik halus pada anak kelompok B PAUD ABC Singaraja semester II tahun pelajaran 2014/2015.Wahyuni (2018) juga menyimpulkan dari hasil penelitiannya yakniterjadi peningkatan kemampuan motorik anak usia 5-6 tahun kegitana cooking class mulai dari observasi yang dilakukan pada tahapan pra siklus mengalami peningkatan dalam setiap siklusnya. Hal ini dapat dilihat dari perolehan angka mulai dari pra siklus sampai siklus II. Dimana perolehan angka rata-rata pra siklus sebesar 39,46\%, siklus I sebesar $53,99 \%$, dan tingginya peningkatan kemampuan motorik halus melalui kegiatan cooking class dari awal pra siklus sampai pada siklus II mengalami 
peningkatan yang cukup signifikan yaitu sebesar 77,46\%. Jannah (2017) melakukan penelitian action researchdengantujuan untuk meningkatkan kemampuan motorik halus melalui kegiatan memasak, dengansubjek penelitian anak kelompok A1 di TK Al-Fitroh Surabaya dengan jumlah 22 anak terdiri dari 11 anak laki-laki dan 11 anak perempuan. Teknik pengumpulan data yang digunakan pada penelitiannya yakni observasi dan dokumentasi. Hasil penelitian menunjukkan adanya peningkatan kemampuan motorik halus anak melalui kegiatan memasak diantaranya kemampuan anak meremas adonan pada siklus I sebesar 63,6\% meningkat pada siklus II menjadi 88,3\%, kemampuan anak menggulung adonan pada siklus I sebesar $63,7 \%$ meningkat pada siklus II menjadi 90,9\%, dan kemampuan anak menekan/mencetak adonan pada siklus I sebesar $63,7 \%$ meningkat pada siklus II menjadi 90,9\%. Kesimpulan yang didapatkan yakni kegiatan memasak dapat meningkatkan kemampuan motorik halus pada anak kelompok A1 di TK Al-Fitroh Surabaya.

Berdasarkan kajian literatur dapat disimpulkan bahwa kagiatan kolase terbukti dalam mengembangkan motorik halus anak tuna grahita ringan karena dengan kegiatan kolase maka perkembangan kemampuan motorik halus anak tuna grahita ringa akan berkembang dengan baik. Kaitan kolase dalam mengembangkan motorik halus anak terletak pada proses kegiatan menempel atau melukis dengan menggunakan jari-jemari tangan dan mata untuk mengontrol, dimana otot-otot kecil anak dapat difungsikan dengan baik, terkoodinasi dengan mata anak sehingga anak dapat menyelesaikan kegiatan menempel di kertas. Kegiatan kolase dapat mengembangkan motorik halus anak tunagrahita ringan terlihat jelas saat anak memegang alat-alat kolase, anak menggunakan alat-alat kolase sesuai dengan fungsinya (memotong, menabur, atau menempel, melukis, dan sebagainya). Kegiatan kolase dapat dikemas dengan cara yang sederhana dan menyenangkan serta aman bagi anak tuna grahita ringa dengan menggunakan peralatan yang aman dan ramah anak serta pengawasan dari guru, orang dewasa, maupun orang tua, maka motorik halus anak tuna grahita ringan akan berlaha berkembang dengan baik maka keberhasilan dari kegiatan kolase dapat disimpulkan bahwa kegiatan kolase sebagai persiapan menulis awal anak tunagrahita ringan

\section{Simpulan.}

Dari kajian literatur yang dilakukan, peneliti dapat menyumpulkan bahwa kegiatan kolase merupakan suatu aktivitas yang menyenangkan bagi anak serta dapat meningkatkan kemampuan motorik halus anak yang tercermat dalam kegiatankegiatan menempel atau melukis yang dilakukan anak bersama guru pada lembaga PAUD. Melalui kajian ini diharapkan kepada guru untuk dapat menjalankan kegiatan kolase ini dengan menggunakan bahan-bahan yang ada disekitar, serta memperhatikan unsur keselamatan bagi anak. Bagi orang tua dirumah juga dapat mempraktekan anak usia dini dalam kegiatan menempel atau melukis di rumah, walau anak masih dalam tahap perkembangan sehingga pembelajaran dari sekolah dapat di ulang kembali di dalam rumah dapat disesuaikan dengan perkembangan dan keamanan anak. Kegiatan kolase dapat mengembangkan motorik halus anak tunagrahita ringan terlihat jelas saat anak memegang alat-alat kolase, anak menggunakan alat-alat kolase sesuai dengan fungsinya (memotong, menabur, atau menempel, melukis, dan sebagainya). Kegiatan kolase dapat dikemas dengan cara yang sederhana dan menyenangkan serta aman bagi anak tuna grahita ringa dengan menggunakan peralatan yang aman dan ramah anak serta pengawasan dari guru, orang dewasa, maupun orang tua, maka motorik halus anak tuna grahita ringan akan berlaha berkembang dengan baik maka keberhasilan dari kegiatan kolase dapat 
disimpulkan bahwa kegiatan kolase dapat meningkatkan motorik halus sebagai persiapan menulis awal anak tunagrahita ringan.

\section{DAFTAR PUSTAKA}

Aisyah Siti, dkk, 2008. Perkembangan dan konsep dasar perkembangan anak usia dini. Jakarta : Universitas Terbuka.

Anggraheni Ika, 2019. Profil Perkembangan Motorik Halus Dan Kreativitas Anak Kelompok B Dalam Kegiatan Cooking Class, THUFULI: Jurnal Pendidikan IslamAnak Usia Dini, VolumeINomor 1Tahun 2019.

Ardy. Novan. W, 2005 Manajemen PAUD Bermutu. Jogjakarta: Penerbit Gava Media jogyakarta

Depdiknas. 2003. Undang-Undang pendidikanNasional No 20 Tentang sistem pendidikan Nasional. Jakarta : Depdiknas.

Danim, P. D. S. 2014. Perkembangan peserta didik bandung : penerbit Alfabeta.

Dwi Nomi Putra. 2019. Perkembangan Motorik Halus Anak Usia Dini Melalui Kolase Media Serutan Pensil:Jurnal Ilmiah Potensia, Vol 4.Nor 2 (Diakses Mei -20 -2020).

Fitri Aida, SyaifulBahri, Fajriani. 2018.Penggunaan Media Kolase Untuk Meningkatkan Kemampuan Gerak Otorik Halus Siswa Tunagrahita Ringan Di Sekolah Sdlb Negeri Banda Aceh : Jurnal Ilmiah Mahasiswa Bimbingan Dan Konseling Vol 3. Nor 4 (Diakses Mei 20 2020).

Juniyanasari Put, Ketut Pudjawan, Putu Rahayu Ujianti, 2015. Penerapan Pembelajaran Kontekstual Melalui Cooking Class Untuk Meningkatkan Keterampilan Motorik Halus Pada Anak. e-Journal Universitas Pendidikan Ganesha Jurusan Pendidikan Guru Pendidikan Anak Usia Dini (Volume 3 No. 1-Tahun 2015).

Murtie, Afin 2017 Ensiklopedia Anak berkebutuhan khusus .jakarta : Penerbit Maxima.

Mulyana Novi, 2018 perkembangan dasar anak usia dini. Yogyakarta: Penerbit gaya media.

Mursid, M. 2015. Belajar Dan Pembelajaran PAUD. Bandung: PT Remaja Rosdakarya

Nur Khasana 2019. Meningkatkan kreatuvitas melalui kegiatan kolase pada anak, : jurnal ilmiah tumbuh kembang anak usia dini volume. 4 nomur 1 (diakses 20-mei-2020).

Nurkhasanah, Alfiyanti 2019. Perkembangan motorik halus anak melalui kegiatan membatik jumputan pada kelompok B3 di RA Ar Raihan bantul yogyakarta :skripsi, universitas islam negri sunan kalijaga (diaksrakan 23 januari).

Paraswati, E. 2013. Membatik Dengan Tepung Untuk Meningkatakan Keterampilan Motorik Halus Anak Di TK Negeri Pembina. Yogyakarta: Skripsi. Universitas Negeri yogyakarta.

Rinarki,A, J, 2018. Pendidikan dan bimbingan anak berkebutuhan khusus, bandung, PT remaja rsdakarya.

Suyanto Slamet, 2005. Konsep dasarpendidikan anak usia dini. Jakarta: depertemen pendidikan nasional direktorat jendral pendidikan tinggi direktorat pembinaan pendidikan tenaga kependidikan dan ketenangan perguruan tinggi.

Sumantri. M. S, 2005. Model pengembangan keterampilan motorik anak usia dini. Jakarta: departemen pendidikan nasional direktrorat jendtal pendidikan tinggi direktorat pembina pendidikan tenaga kependidikan dan tenaga perguruan tinggi.

Setia Ningsih. 2015. Identifikasi Perkembangan Keterampilan Motorik Halus Anak Dalam Berbagai Kegiatan Main Di Kelompok : JurnalPendidikan Guru Pendidikan Anak Usia Dini Edisi 7 Tahun Ke-4 (Diakses 20 Mei 2020).

Siti amsoh. 2016. Meningkatkan memampuan motorik halus anak melalui kegiatan kolase dengan media yang bervareasi pada anak kelompok B ra al mufidah kabupaten tangerang: jurnal ilmiah prosiding ilmiah nasional guru (ting) VIII. diakses $18 \mathrm{mei}$ 2020 